\title{
USING BENTHIC MACRO INVERTEBRATES TO ASSESS WATER QUALITY IN 15 WATERSHEDS IN THE PACIFIC NORTHWEST, USA
}

\author{
R.L. MAHLER ${ }^{1} \&$ M.E. BARBER ${ }^{2}$ \\ ${ }^{1}$ Soil Science Division, University of Idaho, Moscow, ID, USA. \\ ${ }^{2}$ Department of Civil and Environmental Engineering, University of Utah, Salt Lake City, UT, USA.
}

\begin{abstract}
Many government entities have focused on methods to monitor the biological integrity of aquatic ecosystems to address impacts of non-point source pollution. The purpose of this is to determine stream macro invertebrate index (SMI) scores throughout Idaho and to relate these values to observed soil erosion rates and visual estimates of stream water quality. This study took place over a 15 -year period. Based on benthic macro invertebrate sampling, water quality ranged from very good to very poor at the 124 sampling sites in 15 Idaho watersheds. Strong, significant relationships were observed between SMI water quality ratings and observed soil erosion rates. Sites with soil erosion rates of $<2 \mathrm{mt} / \mathrm{ha} / \mathrm{yr}$ generally had SMI water quality ratings of very good. Conversely, when soil erosion rates on adjacent landscapes exceeded $15 \mathrm{mt} / \mathrm{ha} / \mathrm{yr}$, SMI water quality scores were fair or worse. Strong significant relationships were observed between SMI water quality ratings and observed stream water quality in 13 of the 15 studied watersheds. In general, the land use practices in forestry, range, and agriculture adjacent to streams resulted in SMI water quality ratings of good, good, and poor, respectively. Based on the findings of this study, macro invertebrate sampling is considered the best technique for assessing stream quality and is often more economical than the comparative costs of chemical analysis.

Keywords: biological assessment, soil erosion, stream macro invertebrate index, water quality.
\end{abstract}

\section{INTRODUCTION}

Many government entities have focused on methods for monitoring the biological integrity of aquatic ecosystems to address impacts of non-point source (NPS) pollution. The most common and popular method is the use of biological assessments in small streams. Biological assessments incorporate the evaluation of aquatic flora and fauna assemblages within small streams to indicate the potential impacts of NPS pollution on water quality. Using this technique abundance and diversity measures within taxa assemblages are evaluated to determine the condition and ecological integrity of the aquatic systems they inhabit. The use of benthic macro invertebrates has been the preferred method for the biological assessment of small streams for many reasons [1-3].

\section{BACKGROUND}

Biological assessment is a common technique that is used to evaluate the biological integrity of flowing water bodies. When using a biological assessment, inferences can be made about the status or quality of the environment derived from structural and functional attributes of individuals, populations, communities, and ecosystems [4]. Biological assessments attempt to quantify complex ecological processes into a single score often referred to as an ecological health rating. Biological assessments of water bodies have the two following advantages over 
more traditional chemical testing of waters: (1) they are less expensive, and (2) they can detect the compound, and even synergistic effects of pollutants on the environment.

Biological assessments of streams have been developed using algae, bacteria, fish, and benthic macro invertebrates. Benthic macro invertebrates are aquatic organisms found in the bottom substratum of water bodies [5]. Biological assessments rely on indicators, or metrics, to measure the condition of aquatic communities to perturbations [6]. A metric is a characteristic of the biota that changes in some predictable way with increased human influence [7]. Metrics represent different measurements of the sampled biota, such as total number of taxa, percent abundance of the dominant taxon, percent abundance of intolerant groups, and percent abundance of functional feeding groups [8]. Ecological indices often incorporate a multimetric approach to reveal the effects of numerous stressors on the structure and function of the aquatic biota. Water body managers prefer multimetric evaluations because they generate a single score that is comparable to a target value generated from reference conditions [9].

Benthic macro invertebrate populations are the most commonly used community in biological assessments because of the following distinct attributes: (1) macro invertebrates indicate localized conditions because they are relatively sedentary, (2) macro invertebrates indicate integrated short-term environmental impacts due to their short life cycles, (3) macro invertebrates allow experienced biologists (through species identification) to rapidly and easily examine water quality conditions, (4) macro invertebrates possess a wide range of trophic levels and pollution tolerances that allow for comparison, (5) macro invertebrates are good indicators of perturbation on a spatial and temporal scale, (6) macro invertebrates provide a primary food source for fish, (7) macro invertebrates are relatively easy and economical to sample, and (8) macro invertebrates are abundant and diverse in most streams [10-12]. Conversely, there are also limitations for using macro invertebrates. These limitations include: (1) macro invertebrates do not necessarily respond to all human impacts and natural disturbances, (2) numerous samples need to be collected to develop an accurate representation of the ecosystem, (3) variability is inherent throughout the aquatic ecosystem, and (4) runoff and other episodic events can cause declines in localized populations [13, 14].

In Idaho, sediments have been determined to account for up to $75 \%$ of the degradation of surface water quality. Research has shown that stream macro invertebrate index (SMI) scores in flowing water bodies are closely related to adjacent land use and historical management practices [15-17]. The purpose of this article is to determine SMI scores throughout the 15 studied watersheds and to relate these values to observed soil erosion rates and visual estimates of stream water quality. This study took place over a 15 -year period. Consequently, SMI differences over time were also evaluated. This article is a summary of our findings.

\section{METHODOLOGY}

The biological health of surface water at 124 sampling sites in 15 watersheds was determined and expressed using SMI scores [18]. The watersheds chosen for this study ranged in size from 9,355 to 174,600 ha and were located throughout the state of Idaho (Table 1). The benthic macro invertebrate sampling took place over a 14-year period and was initially conducted by graduate students at the University of Idaho. The number of actual sampling sites used in a watershed was dependent on adjacent land use and geography and ranged from 4 to 18 . Common land use in the studied watersheds included forestry, agriculture (cropland), and range (livestock grazing).

At each of the 124 sites, benthic samples were collected using a modified Hess sampler $\left(0.1 \mathrm{~m}^{2}\right)$ based on the guidelines established by Clark and Maret [18]. The collected samples 
Table 1: The year, land use, initial year of benthic macro invertebrate sampling, and number of sampling sites in the 15 Idaho watersheds evaluated for water quality between 2001 and 2011.

\begin{tabular}{|c|c|c|c|c|}
\hline Watershed & Area (ha) & Land use $(\%)$ & Year sampled & Sampling sites \\
\hline Big Boulder & 82,051 & $\begin{array}{l}95 \text { range } \\
5 \text { cropland }\end{array}$ & 2003 & 7 \\
\hline Big Canyon & 36,630 & $\begin{array}{l}50 \text { cropland } \\
50 \text { range }\end{array}$ & 2009 & 9 \\
\hline Clear & 37,050 & $\begin{array}{l}70 \text { forest } \\
25 \text { range } \\
5 \text { cropland }\end{array}$ & 2008 & 10 \\
\hline Cow & 10,268 & $\begin{array}{l}90 \text { cropland } \\
10 \text { cropland }\end{array}$ & 2010 & 7 \\
\hline Crumarine & 1,135 & $\begin{array}{l}80 \text { cropland } \\
20 \text { range }\end{array}$ & 2009 & 6 \\
\hline Fish & 75,740 & $\begin{array}{l}80 \text { forest } \\
20 \text { range }\end{array}$ & 2011 & 8 \\
\hline Jim Ford & 23,843 & $\begin{array}{l}70 \text { forest } \\
15 \text { range }\end{array}$ & 2001 & 18 \\
\hline Lake & 9,355 & $\begin{array}{l}60 \text { forest } \\
40 \text { cropland }\end{array}$ & 2003 & 6 \\
\hline Lapwai & 174,600 & $\begin{array}{l}50 \text { cropland } \\
50 \text { range }\end{array}$ & 2010 & 8 \\
\hline Myrtle & 10,900 & $\begin{array}{l}95 \text { forest } \\
5 \text { cropland }\end{array}$ & 2004 & 9 \\
\hline Orofino & 49,515 & $\begin{array}{l}86 \text { forest } \\
14 \text { range }\end{array}$ & 2002 & 8 \\
\hline Paradise & 11,055 & $\begin{array}{l}80 \text { cropland } \\
20 \text { forest }\end{array}$ & 2007 & 8 \\
\hline Schwartz & 1,531 & $\begin{array}{l}90 \text { forest } \\
5 \text { range } \\
5 \text { cropland }\end{array}$ & 2010 & 4 \\
\hline Silver & 26,772 & $\begin{array}{l}45 \text { range } \\
55 \text { cropland }\end{array}$ & 2005 & 10 \\
\hline Tom Beall & 4,851 & $\begin{array}{l}80 \text { cropland } \\
20 \text { range }\end{array}$ & 2009 & 6 \\
\hline
\end{tabular}

were washed and sorted in the laboratory to remove organic and inorganic debris. Benthic macro invertebrates were visually sorted from the remaining organic material and set aside for identification. A minimum of 300 macro invertebrates from each collected sample were identified to the genus or species level. The data on these macro invertebrate were entered into a software package that calculated 97 different metrics and determined a SMI score based on state of Idaho protocols. SMI scores of 77 to 100,53 to 76,36 to 52,18 to 35 , and 
0 to 18 resulted in ecological heath ratings of very good, good, fair, poor and very poor, respectively.

Erosion rates on lands adjacent to the 124 benthic sampling sites were determined by visual observation in March 2008, June 2008, April 2009, April 2013, and April 2015. The data from the five observation dates were averaged to determine the average annual erosion rate. The visual erosion observations were subjective, but approximated soil erosion rates were $<2$, 2 to 5,5 to 15,15 to 25 and $>25 \mathrm{mt} / \mathrm{ha} / \mathrm{yr}$. Soil texture at the 124 sampling sites ranged from loamy sands to silty clays; however, sandy loams, silt loams, and loams were the most common textural classes observed.

Stream water quality was visually estimated at the 124 sampling sites in March 2008, April 2013, and April 2015 using a developed rating system. Visual water quality rating differences between the observations during March 2008 and April 2015 were noted.

The data were analyzed by relating visual soil erosion rate to SMI water quality rating and dominant land use to SMI water quality rating. Visual water quality rating differences over time were also related to SMI water quality values. Where appropriate, statistics were used to quantify the relations among SMI values, land use, visual erosion rate, and surface water quality.

\section{RESULTS AND DISCUSSION}

The SMI scores for initial water quality ratings at the 124 sampling sites in Idaho between 2001 and 2011 ranged from very good to very poor (Table 2). Approximately 5\%, 24\%, 39\%, $26 \%$ and $6 \%$ of the sampling sites were scored with ecological health ratings of very good, good, fair, poor and very poor, respectively. Based on these and other field observations made in Idaho these scores are typical of surface water quality conditions that would be seen in the state. The relatively high concentrations of cropland in the Paradise, Cow Creek, Tom Beall, and Crumorine watersheds and logging and grazing activities in the Jim Ford Creek watershed were probably responsible for the lower water quality ratings (Tables 1 and 2). Conversely, minimal commercial logging activity in the upper part of the Myrtle Creek and Fish Creek watersheds and significant protected areas in the Silver Creek watershed resulted in higher than average water quality ratings. Within the 15 sampled watersheds there was an excellent range (from very good to very poor) of water quality conditions.

\subsection{Impacts of soil erosion}

Soil erosion rates were visually estimated on land adjacent to and land up to $0.3 \mathrm{~km}$ upstream from each of the 124 sampling sites during high precipitation months in 2008, 2009, 2013, and 2015. Soil erosion rates of $<2,2-5,5-15,15-25$ and $>25 \mathrm{mt} / \mathrm{ha} / \mathrm{yr}$ were observed at $9 \%$, $20 \%, 45 \%, 14 \%$ and $12 \%$ of the sampling sites, respectively.

There was an excellent relationship between observed soil erosion rates and SMI water quality ratings (Table 3). Sites with an estimated erosion rate of less than $5 \mathrm{mt} / \mathrm{ha} / \mathrm{yr}$ were almost always adjacent to sampling sites with an SMI water quality rating of good $(\mathrm{p}=0.02 *)$. Sites with erosion rates of less than $2 \mathrm{mt} / \mathrm{ha} / \mathrm{yr}$ and between 2 and $5 \mathrm{mt} / \mathrm{ha} / \mathrm{yr}$ had similar water quality ratings. Conversely, when soil erosion rates on land adjacent to sampling sites exceeded $5 \mathrm{mt} / \mathrm{ha} / \mathrm{yr}$ SMI water quality scores were less than good $86 \%$ of the time $(p=0.04 *)$ in 2008 and 2009. Land erosion rates of between 5 and $15 \mathrm{mt} / \mathrm{ha} / \mathrm{yr}$ were likely to result in water quality ratings of fair $(\mathrm{p}=0.02 *)$, while higher erosion rates of 15 to $25 \mathrm{mt} / \mathrm{ha} / \mathrm{yr}$ resulted in poor water quality $\left(\mathrm{p}=0.006^{* *}\right)$. When soil erosion rates 
Table 2: Water quality ratings at sampling sites within the 15 Idaho watersheds studied based on metric scores compiled for macro invertebrate evaluations between 2001 and 2011.

\begin{tabular}{|c|c|c|c|c|c|}
\hline \multirow[t]{2}{*}{ Watershed } & \multicolumn{5}{|c|}{-----------------------------Site rating------------------------------------ } \\
\hline & Very good & Good & Fair & Poor & Very poor \\
\hline & \multicolumn{5}{|c|}{------------------------------------- \% -------------------------------------} \\
\hline Big Boulder & 0 & 42 & 29 & 29 & 0 \\
\hline Big Canyon & 11 & 22 & 34 & 33 & 0 \\
\hline Clear & 0 & 40 & 60 & 0 & 0 \\
\hline Cow & 0 & 0 & 14 & 58 & 28 \\
\hline Crumarine & 0 & 0 & 34 & 50 & 16 \\
\hline Fish & 50 & 38 & 12 & 0 & 0 \\
\hline Jim Ford & 0 & 25 & 25 & 38 & 12 \\
\hline Lake & 0 & 17 & 66 & 17 & 0 \\
\hline Lapwai & 0 & 14 & 36 & 36 & 14 \\
\hline Myrtle & 0 & 56 & 44 & 0 & 0 \\
\hline Orofino & 0 & 0 & 75 & 25 & 0 \\
\hline Paradise & 0 & 0 & 50 & 38 & 12 \\
\hline Schwartz & 25 & 25 & 50 & 0 & 0 \\
\hline Silver & 0 & 50 & 50 & 0 & 0 \\
\hline Tom Beall & 0 & 16 & 17 & 50 & 17 \\
\hline
\end{tabular}

Table 3: Relationship between visual erosion estimates made on land in 2008, 2009, 2013 and 2015 that was adjacent to the 124 benthic macro invertebrate sampling locations in 15 Idaho watersheds.

\begin{tabular}{ll}
\hline Soil erosion rate $(\mathrm{mt} / \mathrm{ha} / \mathrm{yr})$ & SMI water quality rating \\
\hline less than 2 & very good \\
2 to 5 & Good \\
5 to 15 & Fair \\
15 to 25 & Poor \\
more than 25 & very poor \\
\hline
\end{tabular}

exceeded $25 \mathrm{mt} / \mathrm{ha} / \mathrm{yr}$, SMI water quality scores in adjacent streams were often very poor $\left(\mathrm{p}=0.05^{*}\right)$.

Based on the 2013 and 2015 erosion estimates at the 124 sampling sites, the relationships between soil erosion rate and water quality rating were confirmed. In 2013 and 2015, sites with an erosion rate of $<5 \mathrm{mt} / \mathrm{ha} / \mathrm{yr}$ were usually adjacent to sampling sites with SMI water quality ratings of very $\operatorname{good}\left(\mathrm{p}=0.006^{* *}\right)$ or $\operatorname{good}\left(\mathrm{p}=0.03^{*}\right)$. When soil erosion rates 
exceed $15 \mathrm{mt} / \mathrm{ha} / \mathrm{yr}$ SMI water quality ratings of poor $(\mathrm{p}=0.04 *)$ or very poor $\left(0.0003^{* * *}\right)$ were noted.

The study findings are significant and show a strong relationship between land use/management and local water quality within Idaho watersheds. Since sediments have been linked to a large portion of surface water degradation in the state, it is important that this study showed the direct relationship between soil erosion (sedimentation) and stream water quality. Simply put, within the 15 studied watersheds, if land management practices are such that erosion is minimal $(<5 \mathrm{mt} / \mathrm{ha} / \mathrm{yr})$ it is likely that stream water quality will be good. Conversely, erosion levels exceeding $15 \mathrm{mt} / \mathrm{ha} / \mathrm{yr}$ are likely to impair adjacent water quality in streams.

\subsection{Visual evaluation of water quality}

Water quality was visually rated at the 124 sampling sites in the 15 watersheds in both 2013 and 2015. A scale from 1 (excellent) to 7 (very poor) was used (Table 4). This visual water quality rating accounted for both water clarity and composition of the substrate on the stream bottom.

Average water quality scores for each of the 15 watersheds are shown in Table 5. Water quality scores ranged from 1.4 in Fish Creek to 5.9 in Clear Creek. There was a good relationship between visual water quality scores and average SMI scores for each watershed (Table 5). For instance, visual water quality scores of 3.5 or less always indicated SMI ratings of good or very good. Conversely, when visual water quality scores were 5.0 or higher watershed SMI scores were always fair or poor.

\subsection{Impact of time on water quality}

Since the data presented in this article were collected over a 15 -year period it was important to evaluate the impact of time of sampling on SMI values, soil erosion estimates, and visual estimates of water quality. Time impacts were noted on SMI values when data collected in 2001 was compared to data from 2015 (Table 6). Differences in soil erosion results occurred when sampling time differences were five or more years (Table 6).

Table 4: Rating scale used to visually evaluate stream water quality at the 124 SMI sampling sites in 2013 and 2015.

\begin{tabular}{ll}
\hline Visual rating score & Description \\
\hline 1 & Water clear to substrate; cobbles cover entire bottom \\
2 & Water clear to substrate; bottom is $50 \%$ cobbles, $50 \%$ sand \\
3 & Water clear to substrate; bottom is over $80 \%$ sand \\
4 & Water turbid, but can see bottom; cobbles cover bottom \\
5 & Water turbid, but can see bottom; substrate is $50 \%$ cobbles, \\
6 & $50 \%$ sand \\
7 & Water turbid, but can see bottom; substrate is at least $80 \%$ sand \\
\hline
\end{tabular}


Table 5: Visual water quality evaluation data averaged for 2013 and 2015 samplings collected in the 15 Idaho watershed locations (124 total samples each year) and average SMI watershed ratings.

\begin{tabular}{|c|c|c|c|}
\hline \multirow[t]{2}{*}{ Watershed } & \multicolumn{2}{|c|}{---------Visual evaluation scores---------- } & \multirow[t]{2}{*}{ Average SMI } \\
\hline & Average score & Score range & \\
\hline Big Boulder & 3.6 & 2 to 7 & fair \\
\hline Big Canyon & 3.9 & 2 to 6 & fair \\
\hline Clear & 5.9 & 4 to 7 & fair \\
\hline Cow & 5.3 & 4 to 7 & poor \\
\hline Crumarine & 4.8 & 4 to 7 & poor \\
\hline Fish & 1.4 & 1 to 3 & very good \\
\hline Jim Ford & 5.7 & 5 to 7 & poor \\
\hline Lake & 5.4 & 2 to 7 & fair \\
\hline Lapwai & 5.0 & 3 to 7 & fair \\
\hline Myrtle & 1.8 & 3 to 7 & good \\
\hline Orofino & 3.8 & 1 to 5 & fair \\
\hline Paradise & 5.4 & 4 to 7 & poor \\
\hline Schwartz & 3.6 & 1 to 5 & good \\
\hline Silver & 2.1 & 1 to 3 & good \\
\hline Tom Beall & 5.0 & 4 to 7 & poor \\
\hline
\end{tabular}

Table 6: Relationship between evaluation date (time) for SMI values, soil erosion estimates, and visual water quality ratings at the 124 sampling locations.

\begin{tabular}{lll}
\hline Parameter & Comparison & Significance \\
\hline SMI values & 2001 vs 2013 & NS \\
& 2001 vs 2015 & $0.04^{*}$ \\
Soil erosion & 2013 vs 2015 & NS \\
& 2008 vs 2009 & NS \\
& 2008 vs 2013 & $0.03^{*}$ \\
Visual water quality & 2008 vs 2015 & $0.006^{* *}$ \\
\hline
\end{tabular}

Sampling time did not impact visual water quality data. In general, time had a very limited impact on the collected data.

\subsection{Impact of land use}

The dominant land use adjacent to and up to $0.3 \mathrm{~km}$ upstream from each of the 124 sampling sites was related to the SMI water quality score (Table 7) in 2008, 2009, 2013, and again in 
Table 7: Relationship between land use and water quality based on 124 sampling site locations in 15 Idaho watersheds in 2008, 2009, 2013, and 2015.

\begin{tabular}{lccc}
\hline Dominant land use & SMI rating & - $2008-09$ & $2013-15$ \\
\hline Forestry (no harvesting) & good & $0.0001 * * *$ & $0.009 * *$ \\
Forestry (harvesting) & fair & $0.038^{*}$ & $0.04 *$ \\
Range & good & $0.046^{*}$ & $0.032^{*}$ \\
Cropland & poor & $0.0001^{* * *}$ & $0.0001^{* * *}$ \\
\hline
\end{tabular}

2015. The four dominant land uses identified in the 15 studied watersheds included: forestry no harvesting, forestry - harvesting, range, and cropland (Table 1). Excellent relationships were found between the dominant land use and SMI water quality rating. As expected, water quality was poorest adjacent to cropland ( $\mathrm{p}=0.0001 * * * 2008-09 ; \mathrm{p}=0.009 * * 2013-15)$.

Water quality in streams adjacent to rangeland was generally good ( $\left.\mathrm{p}=0.046^{*}\right)$; however, the intensity of grazing on these lands resulted in water quality ranging from good (minimal or no grazing) to poor (intensive grazing). Forest management practices influenced adjacent stream water quality (Table 7). Stream water quality was generally fair when the adjacent land had either recently been harvested (clear-cut) or had experienced an uncontrolled burn in the last decade $\left(\mathrm{p}=0.03^{*}\right)$. Conversely, adjacent forestlands, which have received minimal or no harvesting in the last 20 years had good water quality ratings $\left(\mathrm{p}=0.0001^{* * *}\right)$.

\section{CONCLUSIONS AND RECOMMENDATIONS}

The use of benthic macro invertebrates to assess water quality in streams of 15 watersheds in Idaho was successful. The actual sampling of specific macro invertebrate communities resulted in repeatable results. SMI scores based on benthic macro invertebrate sampling yielded water quality ratings similar to both the erosion rate and visual water quality rating techniques. Based on the findings of this study macro invertebrate sampling is the best technique for assessing stream quality and is often more economical than the comparative costs of chemical analysis. In addition, the following observations were made:

- Based on benthic macro invertebrate sampling, water quality ranged from very good to very poor at the 124 sampling sites in 15 Idaho watersheds.

- Soil erosion rates of $<2,2-5,5-15,15-25$ and $>25 \mathrm{mt} / \mathrm{ha} / \mathrm{yr}$ were observed at 9, 22, 41, 21 , and $11 \%$ of the 124 sampling sites, respectively.

- Strong, significant relationships were observed between SMI water quality ratings and observed soil erosion rates.

- Sites with soil erosion rates of $<2 \mathrm{mt} / \mathrm{ha} / \mathrm{yr}$ generally had SMI water quality ratings of very good. Conversely, when soil erosion rates on adjacent landscapes exceeded $5 \mathrm{mt} / \mathrm{ha} /$ yr SMI water quality scores were fair or worse.

- Strong significant relationships were observed between SMI water quality ratings and observed stream water quality in 13 of the 15 studied watersheds.

- A strong relationship between land use/management and adjacent water quality in the 15 studied Idaho watersheds was observed. 
- Watersheds with minimal land disturbance in the last 25 years had visual water quality ratings superior to watersheds with moderate to significant disturbances.

- In general, the land use practices of forestry, range, and agriculture adjacent to streams resulted in SMI water quality ratings of good, good, and poor, respectively.

- The worst water quality in the 15 studied watershed is linked to intensive agricultural cropping systems

\section{REFERENCES}

[1] Grafe, C.S., Idaho small stream ecological assessment framework: an integrated approach, Idfaho Department of Environmental Quality, Boise, Idaho, 2002.

[2] Mahler, R. \& Barber, M., Biological assessments of streams that have been adversely impacted by sediment runoff in Idaho, USA. Annals Of Warsaw University of Life Sciences SGGW Land Reclamation, 42(1), pp. 31-37, 2010. http://dx.doi.org/10.2478/v10060-008-0062-x

[3] Barbone, E., Rosati, I., Reizopoulou, S. \& Basset, A., Linking classification boundaries to sources of natural variability in transitional waters: a case study of benthic macroinvertebrates. Ecological Indicators, 21(1), pp. 105-122, 2012. http://dx.doi.org/10.1016/j.ecolind.2011.04.014

[4] Hart, D.D., Bridges: integrating basic and applied benthic science. Journal of the North American Benthological Society, 13, pp. 110-116, 1994. http://dx.doi.org/10.2307/1467271

[5] Plafkin, J.L., Barbour, M.T., Portier, K.D., Gross, S.K. \& Hughes, R.M., Rapid bio assessment protocols for use in streams and rivers: benthic macro invertebrates and fish. EPA-440-4-89-001. U. S. EPA, Office of Water Regulation and Standards, Washington D.C, 1989.

[6] Omernik, J.M., Ecoregions of the conterminous United States. Annals of the Association of American Geographers, 77, pp. 118-125, 1987. http://dx.doi.org/10.1111/j.1467-8306.1987.tb00149.x

[7] Cairns, J. \& Smith, E.P., The statistical validity of biomonitoring data. In Biological Monitoring of Aquatic Systems, eds. S.A. Loeb \& A. Spacie, Lewis Publishers: Boca Raton, FL, pp. 49-68, 1994.

[8] Cummins, K.W., Bioassessment and analysis of functional organization of running water ecosystems. In Biological Monitoring of Aquatic Systems, eds. S.A. Loeb \& A. Spacie, Lewis Publishers: Boca Raton, FL, pp. 155-170, 1994.

[9] Rosenberg, D.M. \& Resh, V.H., Use of aquatic insects in biomonitoring. In An Introduction to the Aquatic Insects of North America, 3rd edn, eds. W.R. Merritt \& K.W. Cummins, Kendal/Hunt Publishing Company: Dubuque, IA, pp. 87-97, 1996.

[10] Hauer, R.F. \& Lamberti, G.A., Methods in Steam Ecology, Academic Press: San Diego, CA, 1996.

[11] Barbour, M.T., Gerritsen, J., Griffith, G.E., Frydenborg, R,. McCarron, R.E., White, J.S. \& Bastain, M.L., A framework for biological criteria for Florida streams using benthic macroinvertebrates. Journal of the North American Benthological Society, 15, pp. 185-211, 1996. http://dx.doi.org/10.2307/1467948

[12] Karr, J.R., Biological integrity: a long neglected aspect of water resource management. Ecological Application, 1, pp. 66-84, 1991. http://dx.doi.org/10.2307/1941848 
[13] Gerritsen, J., Additive biological indices for resource management. Journal of the North American Benthological Society, 14, pp. 451-457, 1995.

http://dx.doi.org/10.2307/1467211

[14] Reynoldson, T.B., Norris, R.H., Resh, V.H., Day, K.E. \& Rosenberg, D.M., The reference condition: a comparison of multimetric and multivariate approaches to assess water quality impairment using benthic macro invertebrates. Journal of the North American Benthological Society, 16, pp. 833-852, 1997. http://dx.doi.org/10.2307/1468175

[15] Huels, J.P., A biological assessment incorporating benthic macrinvertebrates of the Jim Ford Creek Watershed. M. S. thesis. University of Idaho: Moscow, ID, 2002.

[16] Tosch, M., A biological assessment using benthic macro invertebrates as a water quality indicator for Clear Creek, Idaho County, Idaho. M. S. thesis. University of Idaho: Moscow, ID USA, 2009.

[17] Boeck, J.H., A biological assessment using benthic macro invertebrates of the Myrtle Creek Watershed, Boundary County, Idaho. M. S. Thesis. University of Idaho: Moscow, ID USA, 2006.

[18] Clark, W.H. \& Maret, T.R., Protocols for assessment of biological integrity (Macroinvertebrates) for wadeable Idaho streams. water quality monitoring report, Idaho Division of Environmental Quality, Boise, ID, USA, 1993. 